\title{
Adolescent with Human Immunodeficiency Virus - understanding family beliefs and values*
}

\author{
Adolescente com Vírus da Imunodeficiência Humana - compreendendo crenças e valores da \\ família
}

Patrícia Neyva da Costa Pinheiro ${ }^{1}$, Clarice Mendes de Freitas ${ }^{1}$, Ligia Fernandes Scopacasa ${ }^{1}$, Kelanne Lima da Silva ${ }^{1}$, Fabiane do Amaral Gubert ${ }^{1}$, Izaildo Tavares Luna ${ }^{1}$

\begin{abstract}
Objective: to understand how the beliefs and values of the families of HIV-positive adolescents for Human Immunodeficiency Virus influence family dynamics. Methods: this is a qualitative research with seven family members of adolescents with Human Immunodeficiency Virus, developed in a hospital of reference in infectious diseases. A semi-structured interview was used to collect information. Qualitative research assumptions were applied and the Consolidated Criteria for Reporting Qualitative Research protocol was used for organization and analysis. Results: the family members reported that the adolescents are not perceived as susceptible to infection by the Human Immunodeficiency Virus; they considered AIDS to be a serious disease surrounded by discrimination and prejudice; they identify benefits as guidelines for health and family support. The barriers were difficulty adhering to treatment, teenage pregnancy, "disobedience" and family disharmony. Conclusion: beliefs and values interfere in the way of thinking, acting and caring for the HIV positive adolescent to the Human Immunodeficiency Virus.
\end{abstract}

Descritores: Adolescent; HIV; Culture; Family.

Objetivo: compreender como crenças e valores das famílias de adolescentes soropositivos para Vírus da Imunodeficiência Humana influenciam na dinâmica familiar. Métodos: pesquisa qualitativa realizada com sete familiares de adolescentes com Vírus da Imunodeficiência Humana, desenvolvido num hospital de referência em doenças infecciosas. Utilizou-se entrevista semiestruturada para a coleta de informações. Aplicaram-se os pressupostos da pesquisa qualitativa e o protocolo Consolidated Criteria for Reporting Qualitative Research para organização e análise. Resultados: os familiares informaram que os adolescentes não se percebem suscetíveis à infecção pelo Vírus da Imunodeficiência Humana; consideraram a aids uma doença grave e rodeada de discriminação e preconceitos; identificam como benefícios as orientações sobre saúde e o apoio familiar; já as barreiras foram: dificuldade de adesão ao tratamento, gravidez na adolescência, "desobediência" e convivência familiar desarmonizada. Conclusão: crenças e valores interferem na forma de pensar, agir e cuidar do adolescente soropositivo para o Vírus da Imunodeficiência Humana.

Descritores: Adolescente; HIV; Cultura; Família.

\footnotetext{
*Extracted from Postdoctoral "Family beliefs and values with and hiv seropositive teenager", Tulane University, 2014.

${ }^{1}$ Universidade Federal do Ceará. Fortaleza, CE, Brazil. 


\section{Introduction}

Adolescence is characterized by several transformations in the biopsychosocial and emotional aspects. In this critical phase of life full of changes, important decisions are made for adult life and the construction of personal, sexual and social identity ${ }^{(1)}$.

Doubts and questions are common, mainly related to the topic sex and sexuality ${ }^{(2)}$. This fact demands qualified attention since inadequate information can favor risk behavior, increase individual vulnerability and possible contamination by Sexually Transmitted Infection/Acquired Immunodeficiency Syndrome

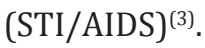

In the midst of the Human Immunodeficiency Virus (HIV) pandemic, the family, with its beliefs and values, must know how to manage crises and live with reality, whether in prevention through dialogue focused on safe sex practices, or living with an HIV-positive member, minimizing prejudices and taboos. In both situations, it is important to understand beliefs and values as well as the knowledge that structures the perception and induce behaviors ${ }^{(4)}$.

The literature recognizes the importance of the family as a support network for people living with HIV/AIDS. Therefore, family members are expected to have a rational approach to the care of HIV positive adolescents influenced by several factors such as personal and social beliefs and values that may facilitate or hinder adherence to treatment, as well as the adoption of care measures of HIV-seropositive patients ${ }^{(5-6)}$.

Knowing the beliefs and values of family members of HIV-positive adolescents is fundamental so strategies can be established to promote health, since, in several situations, the focus of the issue is focused only on the adolescent with HIV, forgetting the importance of the family context in promoting the health of this young person.

Understanding the family life of HIV positive adolescents and contributing to the prevention of
HIV/AIDS and the promotion of family health, this study aimed to understand how beliefs and values of families of HIV-positive adolescents influence family dynamics.

\section{Methods}

This is a qualitative research supported by the Health Belief $\operatorname{Model}^{(7)}$. The research scenario was a reference hospital in infectious diseases in the city of Fortaleza, CE, Brazil, from January and June of 2014.

According to the nature of this investigation, there were was seven family members of adolescents with HIV participating, who passed through the following inclusion criteria: to be accompanying the adolescent during the outpatient visit; to possess emotional and psychological conditions to minimize any discomfort that might arise with the research; and to be over 18 years old. The exclusion criterion was to have some difficulty to continue the interview or refuse to continue the study.

Participants were selected intentionally, through medical chart evaluation, and personally invited to participate in the study. It is worth noting that there were no refusals by the participants to participate and/or to withdraw from the research. The signing of the Informed Consent Term, the participants were informed of the researcher's objectives, reasons, and interests in developing the study.

The information was collected through a semi-structured interview, based on the four constructs proposed by the Health Beliefs Model. The interview questions included: how has it been living with an HIV positive adolescent? What is the relative's perception of this coexistence?

Firstly, there was a previous contact between the student trained for data collection and the principal investigator with the participants in the waiting room of the hospital institution. Then, sound recording was done with the permission of the participants. 
The interview was performed only once for each participant in the institution's outpatient clinic, with an average duration of 60 minutes. There was no need for pilot testing of the collection instrument.

For the analysis of the information, the contents of the interviews were grouped between perceived severity, perceived susceptibility, perceived benefits and perceived barriers, according to the constructs presented in the Health Belief Model, facilitating their codification and categorization of events through two steps: the inventory, which is the act of isolating the elements present in the speeches; And classification, which is the organized division of message elements ${ }^{(7)}$.

The Consolidated Criteria for Reporting Qualitative Research (COREQ) ${ }^{(8)}$ was used to improve the presentation of the results of this research. As part of the secrecy, the participants were called family 1 to 7 .

The study complied with the formal requirements contained in the national and international regulatory standards for research involving human beings.

\section{Results}

Figure 1 shows the synthesis of the characteristics of families of HIV-positive adolescents.

All the relatives who cared for the adolescents were female, evidence that the women are the main responsible for the care, regardless of the marital status, age or education level.

Most of the mothers were HIV-seropositive, with a predominance of vertical transmission during adolescence. Regarding the education level, there was a low level and unfavorable financial condition, with monthly income varying from less than one minimum wage to four minimum wages.

During the interviews, the grandparents and aunts were more communicative and participative, and the mothers were anxious, distant and uninterested, even though they agreed to participate in the study. This fact led to reflection on the possible "guilt" that mothers may have about their child's infection and the emotional overload that may be present in their lives.

\begin{tabular}{|c|c|c|c|c|c|c|c|c|}
\hline $\begin{array}{l}\text { Family } \\
\text { member }\end{array}$ & $\begin{array}{c}\text { Marital } \\
\text { status }\end{array}$ & Age & Serology & Occupation & Education level & Origin & Children & Income* \\
\hline \multirow{4}{*}{ Mother } & Single & 30 & HIV+ & Housekeeper & $\begin{array}{c}\text { Incomplete elementary } \\
\text { school }\end{array}$ & Fortaleza & 4 & $\geq 1$ \\
\hline & Divorced & 33 & HIV- & $\begin{array}{l}\text { Business } \\
\text { owner }\end{array}$ & $\begin{array}{l}\text { Complete Elementary } \\
\text { School }\end{array}$ & Fortaleza & 1 & 1 \\
\hline & Single & 46 & HIV+ & Housekeeper & $\begin{array}{l}\text { Incomplete elementary } \\
\text { school }\end{array}$ & Maranguape & 3 & 1 \\
\hline & Single & 37 & HIV+ & Housekeeper & $\begin{array}{l}\text { Incomplete elementary } \\
\text { school }\end{array}$ & Fortaleza & 2 & 1 \\
\hline Aunt & Married & 44 & HIV- & Housekeeper & Complete High School & Fortaleza & - & 4 \\
\hline \multirow[b]{2}{*}{ Grandmother } & Widow & 49 & HIV- & Housekeeper & Illiterate & Fortaleza & - & 1 \\
\hline & Married & 66 & HIV- & Retired & $\begin{array}{c}\text { Incomplete elementary } \\
\text { school }\end{array}$ & Caucaia & - & 2 \\
\hline
\end{tabular}

Figure 1 - Characteristics of family members of HIV-seropositive adolescents 
The susceptibility perceived by these families was related to contact with the blood of HIV-seropositive adolescents, a fact that increased care with sharp injuries and possible bleeding, such as I prevent her from cutting or injuring herself. I look at my gums and teeth (Family member 2, grandmother).

Despite this understanding, relatives said that living with an HIV-seropositive person did not involve risk, since AIDS is not caught by kissing and hugging and sharing of utensils and objects, and family members have shown knowledge of the forms of infection, the absence of prejudice and care with the virus carrier.

The perceived severity was related to the awareness that AIDS is a serious disease, which can lead to problems related to physical and mental health. They emphasized adherence to treatment, the disclosure of diagnosis and changes in lifestyle as the most common problems.

The adherence to treatment and care was perceived as fundamental so they could avoid complications and have a better quality of life. However, convincing the adolescent was a difficult task, especially when he was unaware of his diagnosis.

Some families did not reveal the diagnosis to anyone, even the adolescents. Others revealed the disease to the adolescent, but excluding family, friends, and neighbors. This situation was justified by the prejudice, discrimination, and social isolation that the person with HIV can suffer.

All this context implies changes in lifestyle, such as the hospital routines involving consultations, exams and treatment, and the adaptations to the new routines and the behaviors of all those involved. He knows about the disease, but he does not want me to tell anybody because he fears being treated differently (Family member 4, mother). The family has prejudice if only one person has the disease (Family member 6, mother). He knows he has an illness, but he does not really know which one. If he asks I do not speak the truth. Fear of counting by the reaction of friends (Family member 7 , mother). They ignore and do not accept the disease, they are not informed and he can worsen the situation there (Family member 5, Aunt). He should take the medica- tion if he will not get worse. He can die like his mother if he does not take the medication (Family member 2, Grandmother).

The perceived benefits were the strengthening of dialogue and affective bonds, especially in those relatives where the diagnosis of HIV infection was revealed to all, strengthening the bonds helped to cope with adverse situations. Guidance on dating, children, condoms and everything the adolescent wants to know is necessary (Family member 4, mother). It is necessary to be affectionate if you do not feel sad. You need to love more (Family member 2, Grandma). Talk a lot and find solutions to problems (Family 3, grandmother). Finally, in the perceived barriers, they emphasized the rebellious, aggressive and suicidal behaviors of adolescents; the presence of feelings of guilt and omission by the mothers; the condition of poverty and the lack of alternatives to reconcile mother's employment with frequent consultations; and the difficulties to perform examinations and care for the good accompaniment of the adolescent. Obstacles that permeated the individuality of the adolescent, the family, and social context, and which assumed different degrees of impact on the lives of those involved were perceived. He does not want to take the medication. He talks all the time that it's his fault that he's got the virus. I stopped working to take care of him. Financial difficulty worsens the situation (Family member 1, mother). We talk and he does not listen (Family member 4, mother). Sometimes the teenager tries to kill himself. I do not tell the truth and I feel bad (Family member 7 , mother). When you want to date and get pregnant, I'll have more concern (Family member 5, Auntie). I do not work every day to take care of the family (Family member 2, grandmother). Increased responsibilities, such as consultations and care (Family member 3, grandmother). He disobeys, he is rebellious and he speaks dirty words.

\section{Discussion}

The study showed two major limitations. The first limitation was the small number of participants, which suggests the existence of HIV-positive adolescents. However, the same study pointed out that adolescents have difficulties in adhering to treatment and do not seek health services. The second limitation 
was the difficulty of establishing limits between the aspects regarding perceived severity, perceived susceptibility, and perceived barriers, because in some situations they were interrelated, differently from perceived benefits, which, although few, stood out from the others.

According to family members, the perceived severity showed that contact with blood is a risk for HIV infection. However, studies say that most people, despite having this knowledge, are not perceived susceptible to a disease, even at risk, whether they are teenagers or not; they do not believe that they can become infected with HIV/AIDS ${ }^{(9)}$.

Adolescents and relatives in this study face several difficulties, including compliance with treatment, the disclosure of diagnosis and changes in lifestyle.

Although necessary, the adherence to treatment is difficult to achieve, since the absence of symptoms, the feeling of limitations and special needs, together with prejudice and discrimination, leading to non-acceptance of the disease. Factors such as medication timings, poor taste, side effects, anxiety, and forgetfulness, as well as the adolescent's unwillingness to take medication may influence non-adherence to treatment ${ }^{(10)}$.

The disclosure of the diagnosis is directly related to the adolescent and to family factors. Thus, the different stages of cognitive maturity can lead to curiosity, questioning, negative psychological reactions and dissemination of their serological status to different people, generating prejudice and discrimination. On the other hand, the family has difficulty exposing their life history with fears, guilts and unpreparedness to face the situation ${ }^{(11)}$.

Prejudice and discrimination deserve prominence as influential elements in lifestyle change, as it is seen as compromising the health of adolescents and can lead to diseases such as depression, due to exclusion and social isolation. Some existing prejudices are related to the fact that AIDS is associated with sexual guilt, fear of possible contagion and erroneous thou- ghts about the ways of infection ${ }^{(12)}$.

For the future, family relationships, as well as the construction of a new family and professional life, are influenced by stigma and discrimination, with the possibility of unequal and marginalized conditions in the face of inequities in relation to unequal opportunities $^{(13)}$.

Adolescence with HIV implies new looks related to sexuality, reproductive health, goals for the future, family, school and professional life. Regarding affective relationships, desires and difficulties stand out, since dating and sexual relationships tend to start, but negotiation about condom use and family planning leads to conflicts and ambiguities ${ }^{(14)}$.

The practice of a dialogue, family support, and affection was perceived as benefits for coping with the problems of family members of HIV/AIDS adolescents.

The frank and open dialogue among family members about HIV is capable of promoting a more harmonious family relationship, as well as better coping with the disease and reducing the anxiety level of those involved. Continued communication among caregivers, health professionals, and the individual with HIV can strengthen links between them and avoid misperceptions about the disease. Open talk about the disease allows greater access to social support and reduces the negative effects of the experience of having a chronic disease ${ }^{(15)}$.

Family support for the HIV adolescent is perceived as fundamental in the context of HIV/AIDS, since the family is a care unit and source of help for these individuals, helping to build mental and physical balance $^{(5-6)}$.

When support means the sharing of emotions, and even in the capacity to put them in the situation of the other and to try to understand the universe in which these adolescents live, the person who receives it has positive attitudes to face the adversities. It is worth emphasizing that when one feels that he/she is understood in a correct and sensitive way, he/she develops a therapeutic attitude towards himself/herself ${ }^{(16)}$ 
The affectivity among the members was perceived as a benefit to the coexistence with HIV infected individuals. This relationship is linked to the feelings of love, affection, responsibility, and concern, making the person who receives them strengthen and have a positive attitude to face adversities ${ }^{(16)}$.

Despite the positive aspects, many barriers were perceived by family members. A similar study found that, besides the caregivers having to face the disease and the treatment, they had to overcome the barrier of the patient's aggressiveness and his disobedience $^{(11)}$. The virus-infected in moments of anger can develop aggressive behavior, compromising the relationship with the caregiver.

Another perceived barrier, which is closely related to the disobedience/aggressiveness of the HIV patient is the difficulty of adherence to medication and medical guidelines. Besides being a barrier, they were also considered to be perceived severity. A study with HIV-positive adolescents and their respective caregivers found the difficulty in adherence to drug treatment as a result ${ }^{(17)}$.

Some people who are already struggling to follow rules, such as adolescents, may develop a blockage in following the prescriptions imposed by the treatment, by the doctor, by the institutions, often leading to aggressive behavior ${ }^{(11)}$.

Besides to this characteristic, at this stage of life, the development of sexuality occurs, fostering the affective and also the sexual relationship. With the onset of sexual life, the relatives of adolescents fear the occurrence of pregnancy, since this phenomenon causes changes in the routine.

Adolescent pregnancy becomes more serious in the context of HIV patient because of the possibility of vertical transmission. The percentage in relation to the risk of contaminating the baby by this type of transmission, that is, by blood or contaminated vaginal discharge is between 25 and $30.0 \%{ }^{(18)}$.

A study on the care of exposed HIV positive pregnant women and newborns has enabled to identify aspects that merit attention because they do not fully comply with the recommendations of the Ministry of Health regarding prophylactic measures of vertical transmission. These gaps between knowledge and care practice show the need for continuing education to achieve safe and effective practices in the prevention of mother-to-child transmission ${ }^{(18)}$.

Pregnant women who are HIV positive show that they are afraid of passing the disease to their child, not being able to care for them in the future and even of dying ${ }^{(19)}$. The blame for vertical transmission is another common feeling among HIV-positive mothers. This study shows the direct relationship between the mother's guilt feelings and the difficulty they feel in revealing the diagnosis of the infection to the child with HIV ${ }^{(16)}$.

This feeling of guilt triggers anguish in mothers, as well as may lead to the development of extreme and divergent behaviors, such as the overprotection of the child, not allowing the development of their independence/autonomy or even distancing themselves from $i t^{(20)}$.

Besides their guilt, denial of the disease is perceived as a barrier to HIV infection. Not only the virus carrier deny the disease, but also their relatives. This fact is evidenced, for example, by the behavior of the daughter of an HIV-positive mother who avoids talking about the disease, which refers to the denial of reality.

The acceptance of a disease and the domain that the individual has over it are considered essential in the fight against a disease. Thus, the fear that relatives have of the adolescents do not accept the disease is very relevant, since this situation will influence how these subjects will treat their health condition ${ }^{(15)}$.

Family members fear that adolescents will be involved in drugs because of other people's influence and their vulnerability. A study indicated that the parents of the adolescents pointed out the group of friends, the need to be inserted and to remain in groups and the curiosity as factors that influence these adolescents in the use and abuse of drugs ${ }^{(16)}$.

Another barrier in the study subjects' lives 
was the low economic level. Thus, financial difficulty and dependence on care increase progressively to the worsening of the disease, and there is a need for greater caregiver resources and dedication ${ }^{(20)}$.

Because of the need to take care of the family member, the caregiver often has his work routine altered. As found, mothers/caregivers who had a formal job reported difficulty in remaining employed, given the increased responsibility attributed to them, such as the need to be present at their children's appointments. Also in the care provided, most of the family members who cared for the adolescents at home believed that they should dedicate themselves exclusively to this task, considering it normal to live on their behalf ${ }^{(15)}$. This is a situation that generates physical and mental distress for the caregiver.

In view of the cultural aspects that involve the family members with HIV-positive adolescents, many difficulties can be evidenced. However, there are ways for actions that may be more effective with this group, such as the practice of home visits of the professionals to these families, training of groups with young people and families in the institutions and the development of other studies to promote the quality of life of those involved.

\section{Conclusion}

Beliefs and values interfere with HIV-positive adolescent care and need to be valued as they influence of thinking, acting and caring. In view of the Health Belief Model used in the study, AIDS was perceived as a serious disease capable of causing harm to health and acting as a negative factor in social and family life.

Prejudice and discrimination were the main causes related to the severity of this disease. On the other hand, the difficulty of adherence to treatment, adolescent pregnancy, adolescent "disobedience" and family disharmony was identified as the main barriers. Despite the negative aspects of the lives of adolescents and families, there were positive elements such as dialogue, family support, health guidelines and acquired learning about the disease.

\section{Acknowledgement}

The Coordenação de Aperfeiçoamento de Pessoal de Nível Superior by postdoctoral funding at Tulane University, USA, Case number 23067-P13389/13-63).

\section{Collaborations}

Pinheiro PNC contributed to the design, data interpretation, writing, critical review of content and final approval of the version to be published. Freitas CM contributed to the data collection. Scopacasa LF, Silva KL, Gubert FA and Luna IT contributed to the relevant critical review of intellectual content.

\section{References}

1. Silveira RE, Santos AS. Contextos de vulnerabilidade entre adolescentes do ensino fundamental de Uberaba/MG. Enferm Foco [Internet]. 2012 [citado 2017 jun 08]; 3(4):182-5. Disponível em: http://www. revista.portalcofen. gov.br/index.php/enfermagem/article/view/380

2. Costa FM, Mendes ACF, Maria DC, Santos, JAD, Costa GM, Carneiro JA. A percepção feminina quanto à vulnerabilidade de se contrair DST/ aids. Rev Universidade Vale do Rio Verde, Três Corações. 2014; 12(2):879-89. doi: http://dx.doi. org/10.5892/ruvrd.v12i2.1744

3. Gomes CM. Vivência em grupo: sexualidade, gênero, adolescência e espaço escolar. Rev APS [Internet]. 2013 [citado 2017 jun 08]; 16(1):10311. Disponível em: http://www. aps.ufjf. emnuvens.com.br/aps/article/view/1470

4. Taquette SR, Meirelles ZV. Convenções de gênero e sexualidade na vulnerabilidade às DSTs/AIDS de adolescentes femininas. Adolesc Saúde [Internet]. 2012 [citado 2017 jun 08]; 9(3):56-64. Disponível em:http://www.adolescenciaesaude.com/ detalhe_artigo.asp?id=331

5. Silva LMS, Tavares JSC. The family's role as a support network for people living with $\mathrm{HIV} /$ AIDS: a review of Brazilian research into the theme. Ciênc Saúde Coletiva. 2015; 20(4):110918. doi: http://dx.doi.org/10.1590/141381232015204.17932013 
6. Acadroli RARS, Silva MA. Conflitos e sentimentos familiares no conviver com o paciente portador de HIV/AIDS. Estud Vida Saúde. 2014; 41(esp):101112. doi: http://dx.doi.org/10.18224/est. v41i0.3811.g2175

7. Rosenstock IM. Why people use health services. Milbank Q [Internet]. 2005 [cited 2017 Jun 28]; 83(4):94-127. Availablr from: https://www.ncbi. nlm.nih.gov/pmc/articles/PMC2690262/

8. Tong A, Sainsbury P, Craig J. Consolidated Criteria for Reporting Qualitative Research (COREQ). Int J Qual Health Care. 2007; 19(6):349-57. doi: https://doi.org/10.1093/intqhc/mzm042

9. Costa ACPJ, Lins AG, Araújo MFM, Araújo TM, Gubert FA, Vieira NFC. Vulnerability of adolescent students to STD/HIV in Imperatriz Maranhão. Rev Gaúcha Enferm. 2013; 34(3):17986. doi: http://dx.doi.org/10.1590/S198314472013000300023

10. Sousa FMP, Luna IT, Silva KL, Pinheiro PNC. Pacientes vivendo com HIV/AIDS e coinfecção tuberculose: dificuldades associadas à adesão ou ao abandono do tratamento. Rev Gaúcha Enferm. 2012; 33(2):139-45. doi: http://dx.doi. org/10.1590/S1983-14472012000200020

11. Paula CC, Padoinn SMM, Brum CN, Silva CB, Albuquerque PVC, Bubadué RM. Cotidiano medicamentoso de adolescentes com HIV/aids. Rev Eletr Enf [Internet]. 2013 [citado 2017 Jun 05]; 15(4):1016-25. Disponível em: https://www.fen. ufg.br/fen_revista/v15/n4/pdf/v15n4a20.pdf

12. Motta MGC, Pedro ENR, Paula CC, Coelho DF, Ribeiro AC, Greff AP, et al. O silêncio no cotidiano do adolescente com HIV/AIDS. Rev Bras Enferm. 2013; 66(3):345-50. doi: http://dx.doi. org/10.1590/S0034-71672013000300007

13. Galano E, Turato ER, Delmas P, Côté J, Gouvea AFTB, Succi RCM, et al. Experiences of adolescents seropositive for HIV/AIDS: a qualitative study. Rev Paul Pediatr. 2016; 34(2):171-7. doi: http:// dx.doi.org/10.1016/j.rppede.2015.08.019
14. Oliveira Filho JS, Silva PE, Freitas FFQ, Soares JP, Costa MAG, Silva ACO. Qualidade de vida de pessoas vivendo com HIV/AIDS. Rev Baiana Enferm. 2014; 28(1):61-8. doi: http://dx.doi. org/10.18471/rbe.v28i1.9088

15. Alvarenga WA, Dupas G. Experience of taking care of children exposed to HIV: a trajectory of expectations. Rev Latino-Am Enfermagem. 2014; 22(5):848-56. doi: http://dx.doi. org/10.1590/0104-1169.3607.2489

16. Galvão MTG, Lima ICV, Cunha GH, Santos VF, Mindêllo MIA. Estratégias de mães com filhos portadores de HIV para conviverem com a doença. Cogitare Enferm. 2013; 18(2):230-7. doi: http:// dx.doi.org/10.5380/ce.v18i2.27630

17. Sales JCS, Teixeira GBSF, Sousa HO, Rebelo RC. A percepção do idoso de um centro de convivência de Teresina-PI sobre a AIDS. Rev Min Enferm. 2013; 17(3):628-34. doi: http://dx.doi. org/10.5935/1415-2762.20130046

18. Barbosa BLFA, Guimarães JV, Salge AKM, Fávaro, LC. O conhecimento dos profissionais de saúde na profilaxia da transmissão vertical do HIV em uma maternidade pública brasileira. Enferm Glob. 2015 [citado 2017 Jun 08]; 14(3):15-28. Disponível em: http://www.scielo.isciii.es/pdf/ eg/v14n39/pt_clinica1.pdf

19. Cartaxo CMB, Nascimento CAD, Diniz CMM, Brasil DRPA, Silva IF. Gestantes portadoras de HIV/ AIDS: Aspectos psicológicos sobre a prevenção da transmissão vertical. Estud Psicol. 2013; 18(3):419-27. doi: http://dx.doi.org/10.1590/ S1413-294X2013000300002

20. Galvão MTG, Cunha GH, Lima ICV. Mulheres que geram filhos expostos ao vírus da imunodeficiência humana: representações sociais da maternidade. Rev Eletr Enf [Internet]. 2014 [citado 2017 Jun 05]; 16(4):804-11. Disponível em: https://www. revistas.ufg.br/fen/article/view/22760 